Walicka M., Wymiana handlowa matych i średnich przedsiębiorstw w procesie konwergencji, „Ekonomia i Prawo", Polszakiewicz B., Boehlke J. (red.), Tom XII, nr 4/2013, ss. 577-588. DOI: http://dx.doi.org/10.12775/EiP.2013.042

\title{
WYMIANA HANDLOWA MAŁYCH I ŚREDNICH PRZEDSIĘBIORSTW W PROCESIE KONWERGENCJI ${ }^{* *}$
}

\section{STRESZCZENIE}

Przystąpienie Polski do strefy euro jest warunkiem koniecznym, strategicznym, a zarazem powodującym daleko idące konsekwencje zarówno dla gospodarki jako całości, jak i poszczególnych uczestników rynku. Celem artykułu jest pokazanie charakteru działalności handlowej małych i średnich przedsiębiorstw (MSP) w kontekście wpływu przystąpienia Polski do strefy euro na ich wymianę handlową z państwami trzecimi oraz członkowskimi Unii Europejskiej. Zaprezentowano literaturę, przeprowadzono analizę zastanych danych oraz przedstawiono wyniki badań ankietowych przeprowadzonych w 2013 r. wśród małych i średnich przedsiębiorstw w województwie podlaskim.

Słowa kluczowe: strefa euro, eksport, import, Unia Europejska, handel zagraniczny Klasyfikacja JEL: F10, D20

* Monika Walicka, Politechnika Białostocka, Wydział Zarządzania, Katedra Finansów i Rachunkowości, ul. Ojca Tarasiuka 2, 16-001 Kleosin, tel. +48 8574698 48, e-mail: m.walicka@ pb.edu.pl.

** Artykuł powstał w ramach projektu „Rola handlu zagranicznego w procesie konwergencji. Przedsiębiorstwa handlowe szanse i zagrożenia w strefie euro" finansowanego przez Narodowy Bank Polski. 


\title{
FOREIGN TRADE OF SMALL AND MEDIUM ENTERPRISES UNDER CONVERGENCE PROCESS
}

\author{
SUMMARY
}

The accession of Poland to the Euro Zone is a necessary, strategic condition, causing far-reaching consequences for the economy as a whole, but also for individual market participants. The purpose of this article is to show the nature of the commercial activity of small and medium size enterprises (SMEs) in the context of the impact of Polish accession to the euro zone trade with third countries and EU Member State. The analysis goal is to indicate if the introduction of common currency affects the size of SMEs' trade with the countries of the European Union, the Schengen area and the euro area.

Keywords: euro zone, import, export, European Union, foreign trade

JEL Classification: F10, D20

\section{WSTĘP}

Wprowadzenie wspólnej waluty w Polsce przyczyni się do zmniejszenia kosztów transakcji handlowych oraz eliminacji ryzyka kursowego. Ma to szczególne znaczenie dla gospodarek otwartych, w których nie są rozwinięte terminowe rynki walutowe ${ }^{1}$. Eliminacja kosztów transakcyjnych może mieć szczególne znaczenie dla krajów, gdzie obroty handlowe koncentrują się wokół jednego lub niewielkiej grupy krajów, mających wspólną walutę. W Polsce prawie jedna trzecia całości obrotów handlu zagranicznego przypada na Niemcy, a na kraje strefy euro ponad 50\% całości wymiany ${ }^{2}$.

Celem artykułu jest analiza wpływu przystąpienia Polski do strefy euro na działalność handlową przedsiębiorstw oraz znalezienie odpowiedzi na pytanie: czy i w jakim stopniu przyjęcie wspólnej waluty może wpłynąć na wielkość handlu MSP. Rozważania przeprowadzane są w stosunkowo wąkim kontek-

${ }^{1}$ Z. Korzeb, Ewolucja ekonomicznych funkcji pañstwa wobec sektora matych $i$ średnich firm, [w:] U. Zagóra-Jonszta (red.), Dokonania wspótczesnej myśli ekonomicznej - teorie nieliberalne wobec ekonomicznej roli państwa a polityka spoteczno-ekonomiczna, AE Katowice, Katowice 2004, s. 371-384.

2 A. Cieślik, J.J. Michałek, J. Mycielski, Analiza skutków handlowych przystapienia Polski do Europejskiej Unii Monetarnej przy u̇̇yciu uogólnionego modelu grawitacyjnego, http://www.nbp.p1/ badania/seminaria_bise/bise_uwO.pdf (26.10.2013). 
ście - kierunków i wielkości wymiany handlowej. Przesłanką do uzupełnienia istniejącego stanu wiedzy były pojawiające się w literaturze przedmiotu liczne spory dotyczące oceny członkostwa w unii monetarnej, a w szczególności przystąpienia Polski do strefy euro. Dostępne opracowania w znacznej mierze opierają się na próbach, w których przeważają przedsiębiorstwa duże. W niniejszym opracowaniu nacisk położono na sytuację małych i średnich przedsiębiorstw, gdyż tak naprawdę to one najsilniej odczują koszty, a także korzyści związane $z$ akcesją. W odróżnieniu od dotychczasowych analiz przeprowadzone badanie uwzględniało specyfikę Polski Wschodniej (województwo podlaskie). Zastosowano metodę badań ankietowych CAWI z użyciem kwestionariusza ankiety. Badanie przeprowadzono w $2013 \mathrm{r}$.

Artykuł składa się z 3 części. Pierwsza stanowi krótki przegląd dotychczasowych publikacji poświęconych uwarunkowaniom współczesnej wymiany handlowej. Kolejna zawiera szacunki dotyczące handlu zagranicznego Polski. Trzecia, ostatnia stanowi prezentację wyników badań. Wnioski końcowe ujęto w zakończeniu.

\section{UWARUNKOWANIA ROZWOJU HANDLU ZAGRANICZNEGO}

Państwa członkowskie Unii Europejskiej (UE) objęte derogacją, aby przystąpić do strefy euro, powinny spełniać poszczególne kryteria konwergencji. Polska obecnie znajduje się $\mathrm{w}$ trakcie procesu konwergencji ze strefą euro (strefa b). W porównaniu $\mathrm{z}$ krajami strefy euro wykazuje wyższy wzrost gospodarczy, ale znacznie niższy poziom PKB per capita ${ }^{3}$. Wśród krajów Europy Środkowej Polska jest jednym z krajów najbardziej zbliżonych pod względem cyklu koniunkturalnego do krajów strefy euro ${ }^{4}$. Współczesna międzynarodowa wymiana handlowa odbywa się przy uczestnictwie wielu państw i gospodarek, na różnych płaszczyznach oraz odbiega od klasycznej koncepcji rozumienia i percepcji handlu zagranicznego. Należy podkreślić, że współczesny handel to nie tylko wymiana dóbr materialnych, ale też praw patentowych, licencji, know-how ${ }^{5}$ czy nawet kapitału. Zmiana wolumenu, zakresu i sposobu organizacji handlu międzynarodowego sprawia, że przyczynia się on do powstawa-

3 Eurostat, National accounts, http://epp.eurostat.ec.europa.eu/statistics_explained /images/7/78/National_accounts_-_GDP_YB2013.xls (15.10.2013).

${ }^{4}$ M. Laszuk, Wptyw przystapienia Polski do strefy euro na wymiane handlowa z krajami Unii Europejskiej oraz z państwami trzecimi, „Ekonomia i Prawo”, t. 12, nr 1/2013.

5 J. Prystrom, Innowacje w procesie rozwoju gospodarczego, Istota i uwarunkowania, Difin, Warszawa 2012. 
nia nowych, dotychczas nieznanych form aktywności ekonomicznej państw, korporacji transnarodowych, podmiotów krajowych, a nawet całych ugrupowań integracyjnych ${ }^{6}$.

O wielkości korzyści z handlu decyduje kierunek prowadzonej polityki handlowej. Wolny handel podnosi poziom dobrobytu krajowego ${ }^{7}$, a redukcja utrudnień handlowych wymaga koordynacji międzynarodowej polityki handlowej. Zniesienie granic pomiędzy państwami sprzyja intensyfikacji transakcji biznesowych, zwiększa wolumen obrotów międzynarodowych i inwestycji ${ }^{8}$. MSP w krajach przygotowujących się do pełnej akcesji do strefy euro powinny odpowiednio przygotować się do nowej sytuacji, uwzględniając w niej specyfikę prowadzonego biznesu, jego umiejscowienie geograficzne oraz charakter prowadzonej wymiany handlowej ${ }^{9}$.

\section{WYMIANA HANDLOWA POLSKI - PODSTAWOWE CHARAKTERYSTYKI}

Polski handel zagraniczny w 2012 r. funkcjonował w dosyć specyficznych warunkach, towarzyszyło mu spowolnienie gospodarki światowej oraz niepewna sytuacja na strategicznych dla Polski rynkach zagranicznych. Wiele gospodarek europejskich dotknęła recesja przejawiająca się nie tylko wzrostem bezrobocia, ale też ogólną niestabilnością finansową. Według szacunków MSZ wzrost gospodarczy Polski w 2012 r. wyniósł 1,9\% PKB (4,5\% w 2011 r.), podczas gdy UE i strefa euro znalazły się w recesji - średni spadek PKB wyniósł tam odpowiednio 0,3\% i 0,6\%. Szybciej od Polski rozwijały się w 2012 r. jedynie państwa bałtyckie: Łotwa 5,6\%, Litwa 3,6\%, będąca członkiem strefy euro Estonia 3,2\% $\%^{10}$. Spośród pozostałych państw regionu w 2012 r. podobne do Polski tempo wzrostu zanotowała Słowacja (2,0\%), nieznacznie PKB wzrósł w Bułgarii (0,8\%) i w Rumunii $(0,3 \%)^{11}$.

${ }^{6}$ J. Rymarczyk, W. Niemiec, Wspótczesne tendencje w handlu międzynarodowym, Oficyna Wydawnicza Arboretum, Warszawa 2007, s. 6-9.

7 MSZ, Euro. Wspólna waluta europejska, Warszawa 2011, s. 2-14.

${ }^{8}$ J. Kundera, Trade Effects of Borders' Elimination. The Case of Poland. „Eurolimes”, No. 13/2012, s. 75-98.

${ }^{9}$ F.J. Greene, L. Travis, Preparations for the Euro by U.K. SMEs with Trading Links with the Euro Currency Area, „Small Business Economics”, No. 19/2002, s. 307-319.

${ }_{10} \mathrm{MSZ}$, Spoteczno-gospodarcze efekty cztonkostwa Polski w Unii Europejskiej, Gtówne wnioski w zwiqzku z dziewiata rocznica przystapienia Polski do UE, Warszawa 2013, s. 3-4.

11 Ibidem, s. 3. 


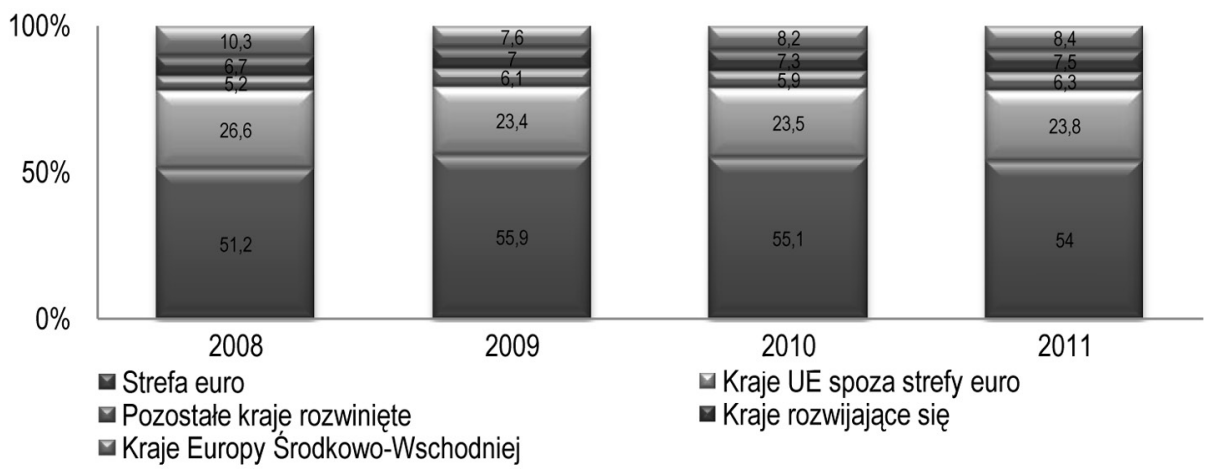

Wykres 1. Udział wybranych gospodarek w eksporcie Polski ogółem Źródło: KUKE, Handel zagraniczny Polski w 2011 r., Warszawa 2012, s. 9.

Sytuacja na rynkach globalnych oraz problemy strefy euro miały swoje następstwa w strukturze polskiego handlu zagranicznego. W 2011 r. spadł poziom eksportu do krajów strefy euro na korzyść krajów rozwijających się i krajów Europy Środkowo-Wschodniej (wykres 1.). Mimo problemów na rynkach głównych polskich partnerów handlowych, głównie w strefie euro, wzrost eksportu w 2011 r. był relatywnie wysoki. Wpływ miała na to przede wszystkim wysoka dynamika na rynkach rozwijających się i słabiej rozwiniętych. Ponad 70\% obrotów polskiego handlu zagranicznego realizowane jest z krajami UE, w tym udział eksportu do tych państw stanowił 76\% eksportu ogółem w 2012 r., a import ponad 57\% importu polskiej gospodarki. W latach 2009-2012 odnotowuje się sukcesywny spadek wolumenu eksportu do krajów UE i strefy euro (tabela 1.).

Tabela 1. Obroty handlu zagranicznego Polski ogółem i wg krajów w latach 2008-2012 (struktura \%)

\begin{tabular}{|c|c|c|c|c|c|c|}
\hline WYSZCZEGóLNIENIE & 2007 & 2008 & 2009 & 2010 & 2011 & $2012 \#$ \\
\hline Eksport & 100,0 & 100,0 & 100,0 & 100,0 & 100,0 & 100,0 \\
\hline Kraje rozwinięte & 84,1 & 83,0 & 85,6 & 84,9 & 84,5 & 82,2 \\
\hline w tym $U E^{*}$ & 78,9 & 77,8 & 79,6 & 79,1 & 78,2 & 76,0 \\
\hline w tym strefa euro* & 52,2 & 51,2 & 56,2 & 55,3 & 54,3 & 52,0 \\
\hline Kraje rozwijające się & 6,1 & 6,7 & 6,9 & 7,1 & 7,2 & 8,1 \\
\hline Kraje Europy Środkowo-Wschodniej j** & 9,8 & 10,3 & 7,5 & 8,0 & 8,3 & 9,7 \\
\hline Import & 100,0 & 100,0 & 100,0 & 100,0 & 100,0 & 100,0 \\
\hline Kraje rozwinięte & 71,1 & 69,3 & 69,1 & 67,2 & 66,9 & 64,1 \\
\hline w tym UE & 64,2 & 61,9 & 61,9 & 59,5 & 59,8 & 57,2 \\
\hline w tym strefa euro & 48,7 & 47,1 & 48,8 & 46,4 & 46,6 & 44,9 \\
\hline
\end{tabular}




\begin{tabular}{|l|c|c|c|c|c|c|}
\hline \multicolumn{1}{|c|}{ WYSZCZEGóLNIENIE } & 2007 & 2008 & 2009 & 2010 & 2011 & $2012 \#$ \\
\hline Kraje rozwijające się & 18,3 & 19,1 & 20,9 & 21,0 & 19,1 & 19,8 \\
\hline Kraje Europy Środkowo-Wschodniej & 10,6 & 11,6 & 10,0 & 11,8 & 14,0 & 16,1 \\
\hline
\end{tabular}

* Obroty z krajami UE obejmują: Austrię, Belgię, Bułgarię, Czechy, Cypr, Danię, Estonię, Finlandię, Francję, Grecję, Hiszpanię, Holandię, Irlandię, Litwę, Luksemburg, Łotwę, Maltę, Niemcy, Portugalię, Stowację, Stowenię, Szwecję, Rumunię, Węgry, Wielką Brytanię, Włochy.

** Obroty z krajami strefy euro obejmują: Austrię, Belgię, Cypr, Estonię, Finlandię, Francję, Grecję, Hiszpanię, Holandię, Irlandię, Luksemburg, Maltę, Niemcy, Portugalię, Słowację, Stowenię, Włochy.

*** Obroty z krajami Europy Środkowo-Wschodniej obejmują: Albanię, Białoruś, Chorwację, Mołdawię, Rosję i Ukrainę.

\# Prognoza MG

Źródło: GUS, Rocznik Statystyczny Handlu Zagranicznego 2008-2012 r., Warszawa 2013; GUS, Obroty handlu zagranicznego ogótem i według krajów I-XII 2011 r., Warszawa 2012.

Spośród rynków strefy euro pogorszenie salda nastąpiło w większości przypadków. Niekorzystne zmiany w strukturze wymiany handlowej z rynkami Niemiec, Francji i Włoch skompensowała poprawa salda z unijnymi krajami nienależącymi do strefy, będąca rezultatem relatywnie szybkiego wzrostu eksportu. Niezależnie od stale zwiększającej się wymiany towarowej, z krajami UE łączą Polskę rosnące powiązania kapitałowe. Wiele przedsiębiorstw z krajów Unii prowadzi działalność gospodarczą w Polsce, a więc sytuacja gospodarcza w Europie wpływa na ich kondycję finansową ${ }^{12}$. Produkowane przez nie wyroby w większości kierowane są na eksport, zwłaszcza do krajów UE.

Tabela 2. Obroty towarowe Polski w latach 2011-2012 r. z krajami strefy euro (mln euro)

\begin{tabular}{|l|r|r|r|r|r|r|r|r|r|r|}
\hline \multirow{2}{*}{$\begin{array}{c}\text { KRAJ } \\
\text { STREFY } \\
\text { EURO }\end{array}$} & \multicolumn{2}{|c|}{ STYCZEN-GRUDZIÉ 2012} & \multicolumn{2}{c|}{ STYCZEN-GRUDZIÉ 2011} & \multicolumn{2}{c|}{ DYNAMIKA } & \multicolumn{2}{c|}{ UDZIAL \% W: } \\
\cline { 2 - 13 } & EKSPORT & IMPORT & SALDO & EKSPORT & IMPORT & SALDO & EKSPORTU & IMPORTU & EKSPORCIE & IMPORCIE \\
\hline Niemcy & 35650,3 & 32057 & 3592,8 & 35664,3 & 34042,1 & 1622,2 & 100,0 & 94,2 & 25,12 & 21,13 \\
\hline Francja & 8274,6 & 6010,2 & 2264,4 & 8371,0 & 6373,8 & 1997,2 & 98,8 & 94,3 & 5,83 & 3,96 \\
\hline Włochy & 6901,8 & 7785,8 & $-884,0$ & 7293,7 & 8234,6 & $-940,9$ & 94,6 & 94,5 & 4,86 & 5,13 \\
\hline Niderlandy & 6340,7 & 5833,4 & 507,3 & 5968,4 & 5717,5 & 250,9 & 106,2 & 102,0 & 4,47 & 3,85 \\
\hline Stowacja & 3637,2 & 3166,1 & 471,1 & 3356,7 & 3151,4 & 205,2 & 108,4 & 100,5 & 2,56 & 2,09 \\
\hline Belgia & 2927,7 & 3381,8 & $-454,1$ & 3177,3 & 3378,7 & $-201,4$ & 92,1 & 100,1 & 2,06 & 2,23 \\
\hline Hiszpania & 2843,1 & 2962,1 & $-128,1$ & 3272,9 & 2993,0 & 279,9 & 86,6 & 99,0 & 2,00 & 1,95 \\
\hline Austria & 2679,1 & 2563,5 & 115,6 & 2617,8 & 2805,1 & $-187,4$ & 102,3 & 91,4 & 1,89 & 1,69 \\
\hline Finlandia & 1056,3 & 1307,0 & $-250,7$ & 1022,3 & 1531,0 & $-508,7$ & 103,3 & 85,4 & 0,74 & 0,86 \\
\hline Estonia & 866,2 & 121,8 & 744,4 & 766,7 & 153,7 & 613,0 & 113,0 & 79,2 & 0,61 & 0,08 \\
\hline Grecja & 507,3 & 290,1 & 217,2 & 596,8 & 362,0 & 234,7 & 85,0 & 80,1 & 0,36 & 0,19 \\
\hline
\end{tabular}

12 W. Czemiel-Grzybowska, Zarzadzanie przedsiębiorstwem spotecznym w procesie konwergencji, Wyd. SEDNO, Warszawa 2012, s. 45-70. 


\begin{tabular}{|l|r|r|r|r|r|r|r|r|r|r|}
\hline \multirow{2}{*}{$\begin{array}{c}\text { KRAI } \\
\text { STREFY } \\
\text { EURO }\end{array}$} & \multicolumn{2}{|c|}{ STYCZEŃ-GRUDZIEN 2012} & \multicolumn{2}{c|}{ STYCZEŃ-GRUDZIEN 2011} & \multicolumn{2}{c|}{ DYNAMIKA } & \multicolumn{2}{c|}{ UdZIAL \% W: } \\
\cline { 2 - 12 } & EKSPORT & IMPORT & SALDO & EKSPORT & IMPORT & SALDO & EKSPORTU & IMPORTU & EKSPORCIE & IMPORCIE \\
\hline Irlandia & 474,2 & 892,1 & $-417,9$ & 397,4 & 777,3 & $-379,9$ & 119,3 & 114,8 & 0,33 & 0,59 \\
\hline Stowenia & 464,6 & 523,3 & $-58,7$ & 464,6 & 519,3 & $-54,6$ & 100,0 & 100,8 & 0,33 & 0,34 \\
\hline Portugalia & 456,9 & 406,1 & 50,9 & 476,9 & 398,8 & 78,1 & 95,8 & 101,8 & 0,32 & 0,27 \\
\hline Cypr & 203,2 & 173,1 & 30,2 & 226,9 & 155,0 & 71,8 & 89,6 & 111,6 & 0,14 & 0,11 \\
\hline Luksemburg & 175,5 & 295,5 & $-119,9$ & 203,9 & 299,3 & $-95,3$ & 86,1 & 98,7 & 0,12 & 0,19 \\
\hline Malta & 36,5 & 27,7 & 8,7 & 61,6 & 37,5 & 24,1 & 59,1 & 73,8 & 0,03 & 0,02 \\
\hline
\end{tabular}

Źródło: DSA MG, Syntetyczna informacja o eksporcie i imporcie Polski za 2012 rok, Dane wstępne, Warszawa 2013, s. 6.

Wiodącym krajem w wymianie handlowej z Polską są Niemcy (tabela 2.). W 2012 r. dodatnie saldo obrotów wygenerowano na handlu z: Francją, Holandią, Słowacją, Austrią, Estonią, Grecją. Jeżeli chodzi o dynamikę eksportu, to najszybciej w ostatnich latach wzrasta wolumen eksportu do Irlandii, Estonii, Słowacji i Holandii. W latach 2011-2012 Polska była importerem towarów głównie z Niemiec, Włoch i Francji, najszybciej zaś rósł wolumen obrotów z Irlandią, Cyprem i Holandią. Najniższa dynamika eksportu towarów z Polski cechuje gospodarki Malty, Grecji i Hiszpanii, importu zaś - Malty i Estonii.

\section{CHARAKTER WYMIANY HANDLOWEJ MSP Z KRAJAMI UE ORAZ Z PAŃSTWAMI TRZECIMI - BADANIA EKSPLORACYJNE}

Analizę charakteru wymiany handlowej przeprowadzono na podstawie badań ankietowych, finansowanych w ramach projektu NBP. Szczegółowy opis metodologiczny ujęto w artykule J. Kilona ${ }^{13}$. Badaniem ankietowym objęto 36 małych i średnich przedsiębiorstw prowadzących działalność handlową na terenie województwa podlaskiego. Ankietyzację przeprowadzono metodą CAWI, obróbkę danych przeprowadzono zaś z zastosowaniem pakietu MS Excel. Analizę przeprowadzono w kontekście dynamiki i charakteru zmian oraz krajów, z którymi badane przedsiębiorstwa dokonują wymiany handlowej. Zmierzono charakter wymiany w postaci wzrostu lub spadku poszczególnej kategorii, w następnie wyliczono wskaźnik wzrostu/spadku mierzony udziałem procentowym importu/ eksportu w obrotach ogółem. W tabeli 3. znajduje się uśrednione statystycznie zestawienie wskazań przedsiębiorców.

13 Zob. szerzej: J. Kilon, Handel zagraniczny w procesie konwergencji - metodyka badań przedsiębiorstw handlowych województwa podlaskiego, „Ekonomia i Prawo”, t. 12, nr 4/2013. 
Tabela 3. Charakter wymiany handlowej podlaskich MSP w latach 2007-2013 z zagranicznymi partnerami mierzony \% obrotów ogółem

\begin{tabular}{|c|l|c|c|}
\hline \multirow{1}{*}{ TendenCJA } & \multicolumn{1}{|c|}{ SKALA } & IMPORT [\%] & EKSPORT [\%] \\
\hline \multirow{4}{*}{ Wzrost } & Do 5\% & 29,2 & 9,1 \\
\cline { 2 - 4 } & $5-15 \%$ & 20,8 & 21,2 \\
\cline { 2 - 4 } & $15-20 \%$ & 4,2 & 15,2 \\
\cline { 2 - 4 } & Powyżej 20\% & 25,0 & 18,2 \\
\hline \multirow{5}{*}{ Spadek } & Do 5\% & 12,5 & 21,2 \\
\cline { 2 - 4 } & $5-15 \%$ & 0,0 & 6,1 \\
\cline { 2 - 4 } & $15-20 \%$ & 0,0 & 3,0 \\
\cline { 2 - 4 } & Powyżej 20\% & 8,3 & 6,1 \\
\hline
\end{tabular}

Źródło: badania własne.

$\mathrm{Na}$ szczególną uwagę zasługuje dynamika importu, cechująca się konsekwentnym wzrostem, najczęściej rzędu 5\% lub 5-15\% - łącznie ponad 51\% wskazań. W 25\% przedsiębiorstw wzrost ten przekroczył 20\%. W nielicznych firmach nastąpił niewielki spadek importu (do 5\%) - 12,5\% wskazań, oraz powyżej $20 \%$ w przypadku $8,3 \%$ badanych. Nie odnotowano spadków w przedziale pośrednim 5-20\%. Inaczej wyglądała sytuacja w przypadku eksportu. Najniższy odsetek przedsiębiorstw wskazał 5\% wzrost, ponad połowa $(54,6 \%)$ odnotowała zaś udział eksportu w obrotach ogółem wyższy niż 5\%, u 21,2\% badanych wystąpiła słaba tendencja spadkowa eksportu (do 5\%), a tylko 15,2\% badanych zauważyło spadek większy niż 5\%. Z analizy charakteru i dynamiki wymiany wynika, że przedsiębiorcy chętnie importują i eksportują. O ile import zwykle stanowi od 5 do 15\% obrotów, to skala eksportu wzrasta w 3 najwyższych przedziałach.

W kolejnej części badania skupiono się nad krajami będącymi najczęstszymi kontrahentami MSP. W tym celu sporządzono ranking takich krajów, na podstawie częstości wskazań poszczególnych partnerów handlowych w badaniu ankietowym (tabela 4.).

Z przeprowadzonych badań wynika, że w przypadku importu najczęstszym partnerem handlowym podlaskich MSP są przedsiębiorstwa z Niemiec. Firmy chętnie importują też dobra i usługi z Belgii, Litwy, Chin oraz Czech i Francji. W przypadku eksportu na uwagę zasługuje fakt, że ponad 58\% badanych eksport kieruje na rynek litewski, ponad $44 \%$ na białoruski, ponad $41 \%$ na niemiecki. Stosunkowo wysoki odsetek badanych, ponad 30\%, wskazywał rynki Wielkiej Brytanii, Belgii, Czech i Rosji. Należy zauważyć, że wszystkie te kraje są członkami Unii Europejskiej. Na uwagę zasługuje fakt, że w pierwszej dziesiątce krajów, z których badani importują, tylko jeden kraj 
nie jest członkiem UE oraz strefy Schengen i są to Chiny. Wśród wszystkich 23 wskazywanych krajów importu tylko 4 nie należą do UE, a 5 nie należy do strefy Schengen. Przedsiębiorcy również chętnie eksportują do kontrahentów z UE. Aż 78\% krajów eksportu to członkowie UE, 73\% należy do strefy Schengen. W pierwszej dziesiątce liderów eksportu pojawia się tu Białoruś, Rosja i Ukraina - kraje znajdujące się blisko wschodniej granicy, więc chociażby ze względu na bliskość rynków i niskie koszty transportu ich obecność w czołówce rankingu wydaje się uzasadniona.

Tabela 4. Kraje z którymi podlaskie MSP najczęściej dokonują wymiany handlowej

\begin{tabular}{|c|c|c|c|c|c|c|c|c|c|}
\hline KRAJ & ODSETEK & & CZŁONKOSTV & & KRAJ & ODSETEK & & ZZŁONKOSTW & \\
\hline & PORT & UE & STREFA & STREFA & & PORT & UE & STREFA & STREFA \\
\hline Niemcy & 36,1 & + & + & + & Litwa & 58,3 & + & + & - \\
\hline Belgia & 25,0 & + & + & + & Białoruś & 44,4 & - & - & - \\
\hline Litwa & 22,2 & + & + & - & Niemcy & 41,7 & + & + & + \\
\hline Chiny & 22,2 & - & - & - & $\begin{array}{l}\text { Wielka } \\
\text { Brytania }\end{array}$ & 33,3 & + & $+^{*}$ & $-^{* \star}$ \\
\hline Czechy & 19,4 & + & + & - & Belgia & 30,6 & + & + & + \\
\hline Francja & 19,4 & + & + & + & Czechy & 30,6 & + & + & - \\
\hline Dania & 16,7 & + & + & $-^{\star *}$ & Rosja & 30,6 & - & - & - \\
\hline Hiszpania & 16,7 & + & + & + & Ukraina & 27,8 & - & - & - \\
\hline Włochy & 16,7 & + & + & + & Hiszpania & 19,4 & + & + & + \\
\hline Austria & 13,9 & + & + & + & Włochy & 19,4 & + & + & + \\
\hline $\begin{array}{l}\text { Wielka } \\
\text { Brytania }\end{array}$ & 13,9 & + & $+^{*}$ & $-^{* *}$ & Bułgaria & 16,7 & + & + & - \\
\hline Węgry & 13,9 & + & + & - & Grecja & 16,7 & + & + & + \\
\hline Holandia & 13,9 & + & + & + & Francja & 16,7 & + & + & + \\
\hline Finlandia & 11,1 & + & + & + & Węgry & 16,7 & + & + & - \\
\hline Szwecja & 8,3 & + & + & - & Estonia & 13,9 & + & + & + \\
\hline Słowacja & 8,3 & + & + & + & Słowacja & 13,9 & + & + & + \\
\hline Stowenia & 8,3 & + & + & + & Austria & 11,1 & + & + & + \\
\hline Rosja & 8,3 & - & - & - & Finlandia & 11,1 & + & + & + \\
\hline Białoruś & 8,3 & - & - & - & Irlandia & 11,1 & + & $+{ }^{*}$ & + \\
\hline Korea & 8,3 & - & - & - & Łotwa & 11,1 & + & + & - \\
\hline Bułgaria & 5,6 & + & + & - & Holandia & 11,1 & + & + & + \\
\hline Cypr & 5,6 & + & - & - & Rumunia & 11,1 & + & - & - \\
\hline Grecja & 5,6 & + & + & + & USA & 11,1 & - & - & - \\
\hline
\end{tabular}

* Tylko w zakresie III filaru

** Klauzula opt-out

Kolorem szarym oznaczono kraje mające traktatowy obowiązek wprowadzenia waluty euro.

Źródło: badania własne. 
Kolejną ważną kwestią jest waluta stosowana w prowadzonej wymianie handlowej. Tylko około $48 \%$ dostawców pochodziło z krajów posiadających wspólną walutę. W ponad $11 \%$ krajów waluta euro zostanie wkrótce wprowadzona na podstawie obowiązku traktatowego, np. Litwa, Czechy, Węgry, Szwecja i Bułgaria. W przypadku eksportu 12 krajów posiadało euro, $6 \mathrm{ma}$ obowiązek wprowadzenia, 1 kraj ma klauzulę ot-out. Pozostałe 4 kraje eksportu to Białoruś, Rosja, Ukraina, USA.

\section{ZAKOŃCZENIE}

Euro jest prawnym środkiem płatniczym, używanym w 17 państwach Unii Europejskiej (28 krajów), poza strefą euro jest zatem 101 krajów. Z tych krajów tylko Dania i Wielka Brytania - na mocy porozumienia z UE (klauzula opt-out) nie muszą, choć mogą wejść do strefy euro. W kontekście przeprowadzonych badań oznacza to, że wymiana handlowa MSP prowadzona jest głównie $z$ kontrahentami posiadającymi wspólną walutę. $Z$ przeprowadzonej analizy wynikają również trzy implikacje na temat działalności handlowej MSP. Po pierwsze, przedsiębiorstwa MSP prowadzą aktywną wymianę handlową, która cechuje się na przestrzeni ostatnich pięciu lat tendencją wzrostową. Po drugie, wymiany dokonują głównie z partnerami unijnymi: posiadającymi wspólną walutę, będącymi w procesie konwergencji lub mającymi traktatowy obowiązek wprowadzenia wspólnej waluty. Po trzecie, specyfika regionu badanej populacji - wysoki odsetek eksporterów na Białoruś, do Rosji i Ukrainy, dająca podstawę do kolejnych, poszerzonych badań procesów handlowych w tym regionie pod kątem wpływu przystąpienia Polski do strefy euro na intensywność tej wymiany.

Podsumowując, akcesja do strefy euro może więc jedynie przyczynić się do ożywienia wymiany handlowej MSP, gdyż zmniejszona zostanie niepewność dotycząca kształtowania się przyszłych przychodów oraz kosztów przede wszystkim podmiotów dokonujących obrotów wewnątrz UE, ale również eksporterów i importerów poza kraje UE.

\section{BIBLIOGRAFIA}

Cieślik A., Michałek J.J., Mycielski J., Analiza skutków handlowych przystapienia Polski do Europejskiej Unii Monetarnej przy użyciu uogólnionego modelu grawitacyjnego, http://www.nbp.pl/badania/seminaria_bise/bise_uwO.pdf (26.10.2013).

Czemiel-Grzybowska W., Zarzadzanie przedsiębiorstwem spotecznym w procesie konwergencji, Wyd. SEDNO, Warszawa 2012. 
DSA MG, Syntetyczna informacja o eksporcie i imporcie Polski za 2012 rok, Dane wstepne, Warszawa 2013, http://www.mg.gov.pl/files/uploa d/8437/Syntetyczna _informa cja_HZ_I_XII_dane_wstepne_20130213_w_ost.pdf (15.08.2013).

Eurostat, National accounts, http://epp.eurostat.ec.europa.eu/statistics_ex plained/images/7/78/National_accounts_-_GDP_YB2013.xls (15.10.2013).

Greene F.J., Travis L., Preparations for the Euro by U.K. SMEs with Trading Links with the Euro Currency Area, „Small Business Economics”, No. 19/2002.

GUS, Obroty handlu zagranicznego ogótem i wedtug krajów I-XII 2011 r., Warszawa 2012.

GUS, Roczniki Statystyczne Handlu Zagranicznego 2008-2011 r., Warszawa 2012.

Kilon J., Handel zagraniczny w procesie konwergencji - metodyka badań przedsiębiorstw handlowych województwa podlaskiego, „Ekonomia i Prawo”, t. 12, nr 4/2013.

Korzeb Z., Ewolucja ekonomicznych funkcji państwa wobec sektora matych $i$ średnich firm, [w:] U. Zagóra-Jonszta (red.), Dokonania wspótczesnej myśli ekonomicznej - teorie nieliberalne wobec ekonomicznej roli państwa a polityka spoteczno-ekonomiczna, AE Katowice, Katowice 2004.

KUKE, Handel zagraniczny Polski w 2011 r., Warszawa 2012, http://www.mg.gov.pl/ files/upload/8437/RoHZ\%202011.pdf (14.09.2013).

Kundera J., Trade Effects of Borders' Elimination. The Case of Poland, „Eurolimes”, No. 13/2012.

Laszuk M., Wptyw przystapienia Polski do strefy euro na wymiane handlowa z krajami Unii Europejskiej oraz z państwami trzecimi, „Ekonomia i Prawo”, t. 12, nr 1/2013, http://dx.doi.org/10.12775/EiP.2013.013.

MSZ, Euro. Wspólna waluta europejska, Warszawa 2011.

MSZ, Spoteczno-gospodarcze efekty cztonkostwa Polski w Unii Europejskiej, Gtówne wnioski w zwiazku z dziewiata rocznica przystapienia Polski do UE, Warszawa 2013.

Prystrom J., Innowacje w procesie rozwoju gospodarczego, Istota i uwarunkowania, Difin, Warszawa 2012.

Rymarczyk J., Niemiec W., Wspótczesne tendencje w handlu międzynarodowym, Oficyna Wydawnicza Arboretum, Warszawa 2007. 
